sufficiently slow. He followed these experiments with others designed to show the "Effects of Compression in modifying the Action of Heat", in which his aim was to demonstrate that when powdered limestone was strongly heated it would, if heated in a confined space, fuse and re-crystallize instead of decomposing. Using gun-barrels and other apparatus of his own design, he succeeded in his objective, obtaining results on which subsequent experimenters were unable to improve substantially for nearly a century, and which clearly show his skill and perseverance at a time when pyrometry and furnace control were in their infancy. Indeed, he opened up an entirely new field of research in chemistry and geology.

Hall's interest in experimental geology continued through his lifetime, and he investigated the effect of lateral compression on bedded strata, and the causes of consolidation of strata. After his death in 1832 some of his apparatus and a number of specimens were presented to the Geological Society of London by his son, Captain Basil Hall, and they are now in the collections of the Geological Museum.

\title{
OBITUARIES
}

\section{Prof. G. W. O. Howe}

THE initials G.W.O.H., familiar to radio engineers throughout the world, passed from currency on November 7 with the death of Prof. George Walter Osborne Howe.

Howe, who was born on December 4, 1875, at Charlton, Kent, and educated at the Roan School, Greenwich, took pride in the long association of his family with riverside London. His forebears were, he used to say, Thames watermen.

After an engineering apprenticeship with Siemens Brothers in Woolwich, Howe became an undergraduate at Armstrong College, Newcastle on Tyne. $\mathrm{He}$ graduated with honours from the University of Durham in 1900 and he had the distinction of being the senior Whitworth Scholar in that yoar.

During 1900-02 he obtained experience in the design of electrical machines at the Siemens-Schuckert works in Berlin, this incidentally being a period in which the German designers of electrical machines were pre-eminent in Europe.

On his return to England, he took up his first terching appointment in the Hull Technical College, and apart from a brief interlude in $1920-21$ at the National Physical Laboratory, where he was head of the Department of Electrical Standards and Measurements, the whole of his long career was devoted to academic work.

It was in 1905 that he was appointed to a lectureship in the City and Guilds College, and there he began to make his major contributions to electrical science. His most notable original work was on radio propagation, the behaviour of radio aerials and on the penetration of high-frequency currents into conductors. His earliest papers show that distinctive quality of mind which was to characterize all his publications and to bring to him in later years a reputation which was truly world wide. His intellectual armoury comprised a superb knowledge of classical electromagnetism, exceptional powers of physical visualization, and the capacity to devise new methods of approach to complex phenomena whereby familiar concepts and relatively simple mathematical methods could be applied.

During 1910-20 he contributed to The Electrician a series of papers dealing in the main with highfrequency phenomena, and he made communications on the same subject to the Proceedings of the Royal Society and to the Journal of the Institution of Electrical Engineers.

In 1921 he was appointed to the newly created James Watt chair of electrical engineering in the
University of Glasgow: At about the same time the monthly journal Experimental Wireless, now Electronic Technology, invited Prof. Howe to become its technical editor. This editorship, which lasted for more than twenty-five years, must be one of the most remarkable in the history of scientific publishing. Every month an editorial appeared over the initials G. W. O. H. Just occasionally the editorial would be of conventional form, commenting in a general way on some development or perhaps on an international conference. The regular pattern was, however, a closely reasoned exposition of some piece of electrical theory relating to a topic of current interest. The article might expose a fallacy, might derive by a brilliant simplification a result obtained in some recently published paper by a recondite method, or might treat a difficulty which had arisen in the course of discussion with his colleagues. Many of the problems which he tackled involved conceptual difficulties of a high order and he would admit to many hours of anxious thought over some of them and, on one or two occasions, to momentary misgivings after he had gone to press. In these editorials, not only was his capacity for clarity of exposition displayed at its best, but also his genius for the apt simile and for witty and sometimes caustic comment had free play. Muddled thinking or obfuscation would sometimes provoke him to a sharpness of witty sarcasm which could give a false impression of him.

Quite early in his career he began attending meetings of the British Association. He became, in due course, secretary and afterwards recorder of Section G (Engineering), and in 1924 president of that Section. He attended three of the meetings which the British Association held overseas-Adelaide in 1914, Toronto in 1924 and Johannesburg in 1929. In January 1938 he went as a member of the official delegation of the British Association to the jubilee meeting of the Indian Science Congress which was held in Calcutta.

During the later part of his life he maintained a direct association with the radio-manufacturing industry as a director of the Mullard Radio Valve Company.

Prof. Howe was elected to associate membership of the Institution of Electrical Engineers in 1905. $\mathrm{He}$ took a prominent part in the formation of the Wireless Section of the Institution in 1919 and he was elected chairman of the Section in 1921. In 1956 the Institution awarded to Prof. Howe the Faraday Medal in recognition of his pioneering work in the study and analysis of high-frequency oscillations and 
of the theory of radio propagation and for his outstanding contributions to engineering education. The Institute of Radio Engineers of New York in 1955 also conferred on him the high honour of election to fellowship of the Institute.

His scientific work apart, Howe experienced his greatest enjoyment in his music. He was an accomplished violinist. He had been taught, he said, when very young on a miniature violin specially made for him, and he could not remember a time when he did not play the instrument. Until a year or two before his death he was an active member of the Glasgow University Orchestral Society.

Only those who had the good fortune to study under him knew the quality of his teaching. He was one of the greatest teachers of his generation. It is hard to escape the conclusion that the main driving force in his scientific work was the urge first to understand, in Clerk Maxwell's boyish phrase, "the go of the thing" and then to expound it. His mind was essentially scholarly, and yet one got the impression that he was intrigued by the unexpected practical implication, the apparent anomaly or the amusingly odd concept rather than by the deeper philosophical implications.

A lively and entertaining companion, a delightful host and an equally delightful guest, Prof. Howe had a wide circle of friends. It was only rarely that the brilliant mind, which in its day-to-day contacts with the world gave the impression of being quietly but confidently self-contained, revealed for a moment that depth of human feeling of which it was capable.

Prof. Howe married in 1901 Sarah Alice Maunder. Mrs. Howe died in 1930.

J. Greic

\section{Dr. Norman Bauer}

Not often is exceptional scientific ability and a deep concern for the welfare of his fellow man combined in one individual. Such an individual was Dr. Norman Bauer.

Dr. Bauer began his studies at the University of California at Berkeley, graduating with a B.S. in chemistry in 1937. He then entered the University of Michigan, receiving his M.S. in 1939 and his Ph.D. in 1941, under the direction of Prof. K. Fajans. He held a scholarship during 1936-37 at the University of California and was Eastman Kodak Fellow at the University of Michigan during 1940-41, and a Post-doctoral Fellow at that institution during 194142.

Desiring to teach, he joined the faculty of the University of New Hampshire in 1942 and remained there until 1945. During this period he was coauthor with Prof. Fajans of the sections on the determination of density and refractometry in Weissberger's Technique of Organic Chemistry, having done much important research in these fields. Due to personal obligations, he returned to Califormia in 1945, where he was employed by the California Research Corporation. Here he became interested in mass spectrometry, publishing articles in this field. In 1949 he founded an independent research laboratory under the name Physical Science Associates at Berkeley. Later, with his personal obligations changed, he returned to academic life, accepting a position at Utah State University in 1953, where he was most recently professor of chemistry.

Here he carried on an excellent programme of teaching and basic research in physical chemistry.
His knowledge and enthusiasm encouraged research in several fields, and many new methods of approaching problems in soil and plant nutrition and in the thermodynamics of the water relations of soils and plants were developed by him. He became interested in the problem of biological nitrogen fixation and made substantial progress in this difficult field, studying the physical chemistry of legaglobins (the proteins involved in nitrogen fixation), establishing a reputation for his laboratory in this topic. Recently, he made significant discoveries that may lead to a major advance in the solution of this problem. Working with electron spin resonance equipment at Varian Laboratories during the summer of 1960 , he detected the presence of free radicals that could be key intermediates in nitrogen fixation. This was especially gratifying to him, since he had predicted theoretically the existence of such radicals in a study of possible pathways for the process. His death on September 9 prevented him from following up this important possibility.

Dr. Bauer was concerned about many problems involving man's welfare. He was opposed to further testing of atomic bombs and personally paid for advertising space to register his protest. He published articles questioning the reasoning of the U.S. Atomic Energy Commission on the hazards of radioactive fall-out. He was particularly concerned with the dangers of nuclear war and spoke out strongly for the cause of peace. He was a champion of the cause of academic freedom, taking an active part in upholding the right of free inquiry. A dedicated scientist, a gifted teacher, he was, in every sense, a man of unquestioned integrity and morals who brought honour to his profession, and a man of good will. JACK T. SPENCE:

\section{Mr. Jaques Cattell}

JAQUeS CATtell, editor of American Men of Science, publisher of the American N'aturalist, and president of the Jaques Cattell Press, Inc., died after a long illness at New York Hospital on December 18; he was fifty-six years old.

In $1923 \mathrm{Mr}$. Jaques Cattell became associate editor of American Men of Science with his father. the late Dr. James McKeen Cattell, and editor following the death of his father. He was also editor of Leaders in Education, founded by his father. The Directory of American Scholars was established by him in 1942, under the sponsorship of the American Council of Learned Societies.

Mr. Jaques Cattell was interested in scientific publishing and the graphic arts. He was president of Science Press Printing Company, and later was a pioneer in the use of cold type composition in scientific publishing. In 1959 he moved to Arizona, and, at the invitation of the President of Arizona State University, continued the publication of his biographical directories from the University campus in Tempe.

$\mathrm{He}$ is survived by his widow, the former Elizabeth Walsh, and his son, James Cattell.

The Jaques Cattell Press, Inc., has announced the appointment of Garrison Cattell and Dorothy Hancock as acting editors of American Men of Science. Mr. Cattell and Mrs. Hancock have worked closely with Mr. Jaques Cattell in editing and publishing this directory. 